\title{
Party Politics And Internal Democracy In Nigeria: People's Democratic Party (PDP) In Anambra State, 2006-2016
}

\author{
Chukwujekwu Onyinyechukwu N., Ezeabasili, Ifeoma Ethel
}

\begin{abstract}
Examines party politics and internal democracy in Nigeria ,specifically the Anambra State Chapter of the People's Democratic Party (PDP). Elite theory was used as the theoretical framework, also the study relied mainly on primary sources of data, descriptive survey design was adopted. The study was analyzed using Simple Percentage and Chi-Square. The study revealed that there is a significant relationship between political 'godfathers' and internal party democracy in PDP in Anambra State; Also is the decision on the composition of party leadership among other manipulations against the interest of the majority of party members.

The study concludes that Internal democracy is the foundation for real expansion of democracy in a developing society like Nigeria. It, therefore, calls for concern when members violate party constitution and display executive arrogance within the party, this act has not only torn many parties apart but also occasioned the decampment of many party stalwarts and crippled internal party democracy in Nigeria.

Based on the findings, the following recommendations were made; hence the influence of godfathers in party politics in Anambra state is alarming, it is, therefore, necessary to adhere to party financial guidelines, re-defining of the legislative framework governing party registrations, functioning, and device measures to limit the role of godfathers and barons in party politics. There is also the need for reform of political financing, that is, the introduction of measures to strengthen parties to raise their own funds and also enhance their capacity to be more accountable and transparent in matters of party and campaign financing.
\end{abstract}

Index Terms - Anambra State, God Father ,Internal Party Democracy, Party Politics, People's Democratic Party,.

\section{INTRODUCTION}

Highlight There is an increasing lack of public confidence and concern on political parties and party politics,across the globe. Political parties have deteriorated in terms of membership, organization, approach. Participation and dedication to democratic ideals (Obah-Akpowoghaha, 2013). . What plays out in Nigeria is not peculiar to Nigeria alone . Since the return of democratic rule in 1999, party activities, especially in the areas of a selection of party candidates, election, responsibility, discipline, etc., appear to be far a way from democratic requirements such that Nigeria democracy

Chukwujekwu, Onyinyechukwu N., Department of Political Science, Federal College of Education (Technical) Umunze. Anambra State,Nigeria Ezeabasili, Ifeoma Ethel, Department of Political Science, Faculty of Social Sciences

Chukwuemeka Odumegwu, Ojukwu University, Igbariam, Anambra State,Nigeria has been the subject of fierce debate . (Obah-Akpowoghaha 2013).

Besides this political parties have been neck-dipped into all manners of anti-democratic activities including electoral manipulations and malpractices during primary and secondary elections. More often than not, both primary and main elections have been characterized by all kinds of unwholesome activities including thuggery, hooliganism, and vandalism, party cross-carpeting, political assassination of political opponents, all of which arises from unfair method of selecting party representatives generally, lack of parties' internal democracy (Dike, 2003).

Evidence from research reports has revealed that most Nigerians believe that inner party democracy does not only affect the reliability of elections but also the quality of leadership, governance and general welfare of the populace (Sartori and Duverger in (Okhaide, 2012). They stressed further that internal democracy is very critical for the functioning of a democratic system in particular and in general progress of the country in general.

Perhaps, no other political party in Nigeria has suffered from the said absence of internal democracy in Nigeria than the People's Democratic Party (PDP) (Egboh\&Aniche, 2012). Just as Odibachi (2010) has observed that party politics has exhibited more crisis than cohesion for national expansion such that virtually all the political parties have been continuously entangled in conflicts due to lack of internal democracy and annoyance of party candidates and party 1 eadership.

Little speculate that the much expected "dividend of democracy" has continued to elude the generality of the people of Nigeria (Egboh and Aniche, 2012).

According to Okoli and Ali (2014), the intra-party opposition, with particular reference to the PDP's experience in Nigeria's Fourth Republic (1999 to date), has been complicated by gross ideological deficits of the party and even other political parties in Nigeria. The remarked that this anomalous phenomenon has led to some untoward outcomes that are inimical to the sustenance of democracy in Nigeria. To them, apart from the crude; a desperate and norm less character that associates with party politics in Nigeria, intra-party opposition demonstrates the culture of partisan indiscipline, loyalty, and supremacy in that context.

Further, intra-party opposition threatens the internal cohesion and integrity of political parties as has been 
observed in the case of the PDP in Anambra State (1999 to date). It has led to the utter destruction of party structures and ethos of the State PDP in such a manner that made it vulnerable to electoral defeat in many elections (Okoli\& Ali, 2014). Therefore, our contention here is that intra-party opposition deepens the crisis of internal democracy in Nigerian State, particularly as it has been within the PDP. The lack of internal party democracy in Nigerian political parties, generally undermines the credibility of the entire electoral process thereby making the entire process undemocratic and therefore difficult to attract any meaningful development for the people.

The issues that have been identified as the bane of party politics or internal democracy in Nigeria by many authors include among others: the issues of Godfathers, party funding, institutional weaknesses and miscarriage of justice due to corruption. However, the issue of Godfathers has been identified as the greatest problem confronting the parties by making them less cohesive and united. This is because it is the godfathers that raises the necessary funds for party routine and campaign activities and as such, he/she has the power to decide the candidate to be imposed or substituted even after the primaries had been conducted (Ojukwu\&Olaifa, 2011; Orji, Eme\&Nwoba, 2014; Nkwede, Ibeogu\&Nwankwo, 2014; Obah-Akpowoghaha, 2013 and Nwagwu, 2016).

This is also the case of PDP in Anambra State where the party is often factionalized along with parallel party executives and emergence of two or more party candidates contesting this same electoral position in the same election. In most cases, the above is as a result of parallel party congresses and conventions in which the party gladiators usually try to impose their favoured candidates on the party. The formal party structures have been hijacked by godfathers who have a direct connection to the presidency, and who use it to impose their godsons on the party. Thus, the outcomes of most party congresses and conventions are disputed and contested in courts. The internal mechanism for dispute resolution in the party is often not followed or exhausted before rushing to courts because of lack of faith in its ability to dispense justice without fear or favour or resolve disputes fairly and justly. This was evident right from the inception of the party and during the 1999 gubernatorial and legislative primaries in Anambra State (Ogbeide, 2012; Okoliand Ali, 2014; Olorungbemi, 2014; CDD, 2017).

The paper, therefore, examines party politics and internal democracy in Nigeria with a specific focus on PDP in Anambra State between 2006 and 2017.

Very few scholarly works have examined internal party democracy in Anambra State PDP. Yet most of them like Ogbeide(2012), Okoliand Ali (2014), Olorungbemi(2014), and CDD (2017) only discussed the cases of political Godfathers in PDP in Anambra State sparsely in terms of political unrest, impasse, crisis, and instability; as one of the instances of the effects of political 'Godfathers' on internal party democracy in Nigeria generally. Thus, they were not able to adequately and empirically address; one, the nature of the relationship between political 'Godfathers' and internal party democracy in PDP in Anambra State; two, the nature of the relationship between weaknesses of the regulatory institution internal democracy in Anambra State.

\section{LITERATURE REVIEW}

\section{Politics, Internal Democracy, and Political 'Godfathers'}

Party politics are those activities of political parties in a democratic environment to seek for the control of political offices through stated norms of election (Olaniyi, 2001). Party politics exist when elective principles are present in a state and by implication under a democratic regime which recognizes the legitimate choice of the citizens to select or elect those to represent them in governmental offices.

According to Okoye (1982), party politics, are activities of formal structure, institution or organization which compete through the electoral process to control the personnel and policies of the government, and with the objective of allocating the scarce resources in a state through an institutionalized means or procedure', Hence, the primary objective of party politics is directed toward a single goal of wrestling for governmental or political power.

There is no generally accepted definition of the concept of Intra Party democracy (Internal Party democracy) although many scholars agreed on some basic principles of accountability, transparency, inclusivity, participation, and representation (Duverger, 1963). Internal Party democracy means that the party should be formed "bottom-up" and that the internal distribution of power should be marked by dispersion at different levels, bodies, and individuals rather than by the concentration in one organ (Giovanni, 1977).

Building up from the study of Scarrow (2004), he argued that internal democracy is a term used to describe a wide range of means for including party members in internal party deliberation and decision making. Also, Mersel (2006) is of the view that Internal Party democracy is aimed at increasing more representative, transparent and effective political parties. It recognizes the specific tasks in the internal organization and functioning of parties and party systems; including; candidate and leadership selection; policy-making; membership relations; women and youth inclusion and party funding.

Teorell (1999) examines two essential contributory elements of internal party democracy. The first involves organizing free, fair and regular elections to fill internal positions, as well as selecting candidates for representative bodies. The second involves equal and open involvement of all members and groups in such a way that interests are more representative. These two mechanisms are essential for creating a transparent, open and purposeful political party in which creating an open and deliberative political party people can participate in elections equally but may also engage in participation or be represented in other ways.

Internal Party democracy according to Gosnell(1968), is that which provides necessary vertical linkages between different deliberating spheres and horizontal linkages between competing issues. It refers to the creation of a permissible climate within a political party which guarantees 
the participation of all party members in decision making as well as general administration of the party. Such climate fosters the active involvement of every party member and not a few powerful rich.

Within the sphere of a conceptual framework, major concepts such as godfather, political party funding, political party, etc., were scholarly defined. For instance, Orji (2014) has defined Godfathers as the power of an individual over the machinery of a political party, its constitution, statutory laws, and the Nigerian Constitution. Therefore godfathers are a major plague of party politics in the country and are specifically, responsible for fractionalization, acrimony, and conflict ( IDEA, 2006). To Ibeanu (2008), godfathers are the major financiers of the PDP and its electoral candidates and the use the party as an "astutely thought out investment outlet to be recovered through frivolous and bloated government contracts, appointments of Glories into chosen public offices and other prebendal returns by the beneficiaries." Godfathers has led to the personalization of the party, siphoning of public resources, embezzlement, mismanagement, and outright theft. According to Chukwuemeka, Oji and Chukwurah (2013), the concept of Godfathers is a kind of politics whereby an influential person in a popular or ruling party will assist someone usually a lackey, i.e., godson to emerge as the governorship candidate of a party at all cost and either by hook crook, he, he will help him to emerge victorious in the state governorship election irrespective of whether he is a populace candidate or not. Intuitively, therefore, political Godfathers represents a self-seeking individual out there to use the government for his own purposes. The cost of this incidence is enormous to the state as what usually obtains is that when the incumbent godson is at pains to satisfy the whims and caprices of the godfather among other competing demands on the scarce resources of the government, the larger members of the society suffers.

\section{EFFECTS OF 'GODFATHERS ON INTERNAL DEMOCRACY}

The emergence of godfather in the Nigerian political scene is posing a great threat not only to political parties but also to good governance, socio-economic development, and stability of democratic governance (Chukwuemeka, 2012). He states that one of the most disturbing and damaging influences of godfathers in Nigeria's fourth republic is in the domain of making nonsense of a truly free, fair and credible electoral process in which the electorates by right are expected to freely elect people of their choice into public office to represent their interests. In a study titled "political godfathers and governance in a developing democracy: insight from Nigeria, Nkwede, Ibeogu, and Nwankwo (2014) used descriptive and content analysis to investigate whether political Godfathers affects good governance in Nigeria. The study found that Godfathers has threatened the country's nascent democracy. The study concludes that among other thing, competitions among godfathers to control state powers and resources through their favoured godsons and daughters have denied the electorate the right to elect their preferred candidates, thereby rendering elections and electoral processes ineffective to the disenchantment of other party members. Besides this, the struggle for control of state power has also resulted in some worst electoral violence in the country.

In Nigeria, the majority of the people regard godfather phenomenon as a huge challenge to internal democracy. This is because the godfathers use their influence as the major financier of the party to impose candidates on the people or substitute a candidate who has been duly elected to fly the flag of the party during general elections. The imposition or substitution are always necessitated by disagreement between the godfather and the godson on what should be gains of the godfather (Ikejiani-Clark, 2008). As Ngige (2008) has observed, the magnitude of the mafia-style phenomenon of godfathers $\mathrm{s}$ also demonstrated by how the godfathers decide party nominations and campaign outcomes. He noted further that when candidates resist the godfathers use violence to deal with the situation. He posits that the godfathers are mainly interested in controlling the party machines instead of presenting popular candidates for healthy electoral competitions. He observes that with such control of the party organization, godfathers cum PDP has various ways of eliminating popular candidates from the so-called party primaries. The problem, however, is that when such unpopular candidate eventually becomes the winner through manipulations in the election, he/she enjoys less support because the godfather will always be around to recoup his investment and when the godson refuses to honour the agreement, war always ensues between them.

For instance, Bassey and Edet (2008) observed that in Anambra State, the problem of Godfathers has done more harm in the PDP than in any other place, particularly in the gubernatorial position taken at different times. As the recounted, from 1999-2003, the battle was between Dr.ChinwokeMbadinuju and his godfather, EmekaOffor. Dr.Mbadinuju refused to dance to the tune of his godfather and as a consequence, Mbadinuju lost bid for the second tenure as the pressure from his godfather made him perform far more below expectations in governance. The bickering and acrimony raised by the two actors are yet to settle when two others emerged. Chief Chris Uba and Dr. Chris Ngige.Uba was the godfather of Ngige as the governor of Anambra State, 2003-2006. Ngige refused to pay back his godfather the necessary commission and patronage. Since then, peace never returned to the seat of power in Anambra State. Eventually, appeal court declared Mr. Peter Obi as the winner of the 2003 gubernatorial election in Anambra State in March 2006 and this marked the beginning of scattered elections in Nigeria in this political dispensation (Ogbeide, 2012; Okoliand Ali, 2014; Olorungbemi, 2014; CDD, 2017). Similar situations occurred in Enugu State, Ebonyi and Oyo States. Therefore, candidate imposition by godfathers does not only affect the party's internal democracy but also the generality of the people who would be or are always at the mercy of the godfather in terms of welfare that would have come from good governance (Kura, 2014; Badejoand Obah-Akpowoghaha, 2015; Okonkwo and Unaji, 2016; Okafor and Aniche, 2017).

Since the inauguration of the Fourth Republic in Nigeria in 1999, the case of Anambra State has been a confounding one. It is the only state that has paraded five governors under 
controversial circumstances from 1999 to 2007 (Ogbeide, 2012; CDD, 2017). The electoral history of the state since the country's return to democratic rule in 1999 is full of political notoriety. From 1999-2013, the State created a new record in Godfathers. First was the Ofor-Mbadinuju saga (1999-2003),Uba-Ngige comedy (2002-2006) (Okoliand Ali, 2014; CDD, 2017).

\section{Regulatory Institutions and Political Parties' Internal Democracy}

The subsisting laws that guided 2003, 2007, 2011 and 2015 elections have gone through a series of amendments to strengthen its content in keeping with realities. The law assigns the Independent National Electoral Commission (INEC) with the responsibility of registering and regulating party activities, superintend over party primary elections, and to exercise oversight functions overall financial transactions of all political parties (Nwagwu, 2016). He notes that the instrument has been poorly enforced as the regulatory agency is overwhelmingly too weak to enforce the law because it lacks enforcement capacity to arraign those who have breached the law, incompetent to moderate party financing and campaign donations and partisan in implementing the clauses of the Act that deals with defaulting cases. He is of the opinion that the provisions of the Electoral Act have been grossly and variously violated by political parties, their financiers and others. Yet there has been no investigation, arrest or prosecution of defaulters for contravening the law, he reiterated.

According to Ofuebe and Anierobi (2005), the Transition Monitoring Group (TMG), a coalition of 170 human rights and civil society organizations in 2003 notes:

The electoral process was undetermined by the conduct of the primaries of many of the political parties, especially the PDP since "godfathers" foisted their preferred candidates on the parties through undemocratic processes .... The President and all Governors of the 36 states schemed to get the second term and used their incumbency to intimidate any opposition through the deployment of state resources to win at all cost.

This, in their opinions, is in spite of the fact that the constitution rules generally that the internal workings and decisions of the political parties must conform to democratic precepts declaring INEC as the umpire. However, it is doubtful if INEC is truly the umpire because most of the atrocities committed in the political parties primary elections are usually under the watchful eyes of the INEC functionaries, they reiterated. Therefore, INEC as a regulatory institution in election matters in Nigeria has failed to live up to expectation, especially in the areas of effective monitoring and supervision of political parties primary elections. In fact, it has been alleged that most of the impositions or candidate substitutions often carried out by party stalwarts are in connivance with the INEC officials thereby disrupting the process to create an atmosphere of crisis within the parties (Omeje, 2010). This, perhaps, is the reason that he submits that internal party democracy is one issue that has consistently eluded Nigerian democracy because political parties have always been hijacked at all levels by powerful individuals who impose loyalists or sycophants as candidates for elections. He remarks that the lack of internal democracy has been the bane of Nigeria democracy.

\section{Challenges OF INTERNAL DEMOCRACY}

In the work of Ojukwu and Olaifa (2011) studied the challenges of internal democracy in Nigeria's political parties, perceiving it as the bane of intra-party conflicts in the Peoples Democratic Party of Nigeria. The study which adopted content analytical design found that non-observance of the code of conduct document which all the political parties assented to and endorsed to guide their conduct and performance, particularly during elections, was a major problem. It was also found that the non-transparent system of choosing or electing candidates during primary elections as well as in choosing party leadership in addition to executive arrogance within the parties have torn many parties apart thereby leading to decampment of many party stalwarts. It was concluded that there should be definitive respect for the will of the majority for intra-party conflicts to reduce so that internal democracy may be achieved and sustained.

In a related study carried out by Obah-Akpowoghaha (2013) on party politics and the challenges of democratic consolidation in Nigeria, descriptive survey design was employed, and the Findings revealed that the majority, more than 90 percent of the respondents are of the view that money and class were the major factors that determine the position of candidates in Nigerian elections and not the capacity to deliver. Also, more than 90 percent again agreed that the power of incumbency and Godfathers greatly determines the emergence of party candidates. The study conclude that party politics in the area of nomination, selection and elections have negative impact on democratic consolidation in Nigeria.

Also, the work of Mommodu and Matudi (2013) on the implications of intra-party conflicts on Nigeria's democratization. The study adopted content analysis. From the findings, it was obvious that intraparty conflicts are engendered primarily because of the insatiable greed of political elites which creates access for primitive accumulation of the Commonwealth of the people. It has also led to the fractionalization of some major political parties and the consequence if decamping of party members.

Furthermore, Lamidi and Bello (2015) examined party politics and the future of Nigerian democracy: An examination of the fourth republic, qualitative analysis was adopted. The study found out that political parties since 1999 have not been able to engage in issues that will stabilize democracy in Nigeria. Political parties that are expected to perform integrative roles and engage in nation building are busy with internal crisis; they instigate the tension created by division and tribal loyalty, as they hold onto politics of exclusion such as a denial of wider participation by the citizens. They spent more time or internal crisis than the implementation of policies that will help the majority of the electorates.

However, Aniche (2017) made an illustration on how lack of internal party democracy within PDP served as one of the major variables determine the outcomes of 2015 General 
Elections in Nigeria leading to the emergence of APC as the ruling party. In other words, it transformed PDP from ruling party to opposition political party and APC from opposition political party to the ruling party. Though his study was at the National level, thus, failed to focus on PDP in Anambra State.

\section{History of the PeOPle's Democratic PARTy (PDP)}

The formation of People's Democratic Party dated back to the historic step taken in 1997 by a group of 18 (G18) eminent but angry Nigerians known as G18.

People's Democratic Party has a long history. It is argued that the genesis of the party was the Institute of Civil Society (ICS) established in 1997 purposely to create awareness among Nigerians about their rights and responsibilities in a militarized political atmosphere (Kuru, 2011). This was the era when military rule reached its climax in Nigeria, characterized by political assassination, murder, kidnapping, and intimidation. The Institute of Civil Society (ICS) later metamorphosed into a group of 18 (G18) eminent but angry who are dissatisfied about the militarized political atmosphere. The greviances of this group led by Alex Ekwueme (Nigeria's former vice president in the second republic) was Abacha's militarization of the political space and his perceived plan to transform himself into a civilian president at the end of his transition program in 1998 (Osumah\&Ikelegbe, 2009).

This group later increased its membership to 3 and became known as G34. The main objectives was the total and unconditional demilitarization of Nigerian politics. It is called for democratization and even gave Abacha a deadline for the transfer of power to civilians (Osumah \& Ikelegbe, 2009). Before Abacha could respond to the demands of the group, he died together with the perceived self- succession plan. Power changed hands and, under Abubakar, the political space was open to interested political players. With this development, a number of political associations mostly those denied registration by NECON under Abacha's regime such as All Nigeria Congress (ACN), People's Consultative Forum (PCF), Social Progressive Party (SPP), People's Democratic Movement (PDM) and People's National Party (PNP) joined G34 and formed a single umbrella organisation - the People's Democratic Party (PDP) with Solomon Lar as its pro tem chairman. The party was registered with INEC on 28th July 1998 (Akubo\&Yakubu, 2014).

The party general membership drawn from traditional chiefs, academics and businessmen and proved especially popular with the army, including Obasanjo Olusegun, a former military leader of Nigeria (1976-1979) under his direction the People's Democratic Party quickly became the country's dominant party.

This paper was anchored on Elite Theory as propounded and expounded by Vilfredo Pareto, Gaetano Mosca, Robert Michel, among others. The major assumptions of an elite theory is that in every society, there is and must be minority who rule over the rest of the society, and this minority forms the political class or governing elite, composed of those who occupy the posts of political commands and more regularly, those who can directly influence political decisions. They undergo changes in its membership over a period of time, ordinarily by the recruitment of new individual members from the lower strata of the society, sometimes by the incorporation of new social groups and occasionally by the complete replacement of the established elite by counter-elite (Pareto, 1935; Burnham, 1960; Varma, 1975).

This view, thus, identifies two principal classes in any modern society, which are the Elites and the Masses. For them, elites have more access to political power despite their numerical minority, and therefore wield political power in every society as such they are the ruling class, while the masses are the ruled-class despite their numerical majority or strength. There is, therefore, for them a single-ruling elite that occupies the apex of the pyramid of power, while the masses (of the people) occupy the base of the pyramid of power (Putnam, 1976; Bottomore, 1993; Mills, 2000).

The elites rule because they have more access to wealth and information, therefore, they are well-informed, well educated, better organized, cohesive, unified, conspiratorial and more politically conscious, while the masses are mainly poor, ill-informed, disorganized, lack cohesiveness, poorly educated and in some cases apolitically or politically apathetic or less conscious. Ascendance to the elite position is, therefore, gradual or incremental not revolutionary (Pareto, 1991; Varma, 1975; Dye, 2000).

For example, Robert Michael insists that society is divided into two, (a) those who rule and (b) those that are ruled. Michels(1915) predicated his Iron Law of Oligarchy on this ground, that even if we level the society that there is inevitable tendency for a small group of people to rise to the top to separate themselves from the rest economically, socially, culturally and politically, from where they run the affairs of the society within a very short possible time (Nnoli, 1986).

Scholars such as Saint Simon, Hippolyte, Ludwis, Karl Marx, Vilfred Pareto, Gaetano Mosca, posit that in every branch of human activity each individual is given an index which stands as a sign of his capacity, very much the way grades are given in the various subjects in examinations in school (Suenu, 2004; Nkwede, 2014). According to Suenu(2004), the leading proponent of elite theory paradigm, an elitist correlation to the understanding of Godfathers is very apt. He sees Godfathers as being synonymous with the elites. For him, elites in the political spheres are known in Nigerian context as godfathers. They are the ones who govern and are known as the king-makers, they are notable and are often seen as strongmen who control politics in their different domains. Apparently, in a political environment where Godfathers is vogue, individuals are colonized by the godfathers. In other words, godfathers rule by proxies.

This theory is apt because the issues under investigation can effectively be analyzed under the framework of the theory. Its interconnectivity to the explanation of political Godfathers and the degree of disruptions it causes in intra-party affairs arising from their (godfathers) desires to occupy the governance position at all costs so that they can appropriate all financial resources accruing to the people, to themselves and associates. 
However, in Nigeria, the activities and efforts of the elites (political class, godfathers) is so manifest that, before the end of recruitment proceeds or election that results have been predetermined and if there is contrary outcome on the proposed results, the elites attempt to use economic and political means to influence the results. This was very rampant in various elections (1999, 2003, 2007 and even 2015 ) in the country at the state and national level. A case in point is the political conflict between the then party chairman of PDP, Chief Audu Ogbeh and former President Obasanjo which led to the forceful removal of the former chairman of the party. Other examples are evident in the pattern of cross-carpeting of politicians, the emergence of factions' executive within the same political party. The above points buttress Gaetano Mosca and Robert Michaels views that the elites possess economic power and control the political system.

This implies that, the political elites are so powerful that they acquire political power through the imposition of candidates, electoral rigging. This explains the actios of political parties on the elites in terms of interest articulation and aggregation

However, certain actions are common to PDP Anambra State chapter, such actions include the imposition of candidates, leadership tussle among party members, multiple candidates selection, etc. thereby harnessing the control of the political elites in the party.

The population of the study consists of all PDP party executives and stakeholders. They include 12 state party executives, 15 stakeholders, 5 persons each from the 326 electoral wards in the state making a total of 1657 persons.

Determination of Sample Size

The sample size of the study was determined through the Taro Yemeni's formula for determining sample size from a finite population. The procedure is as follows:
Where:

$\mathrm{n}$ = sample size to be determined

$\mathrm{N}=$ the entire population of interest

e $=$ error term $(0.05)$

1 = constant

Substituting the values in the formula, we have:

$$
\begin{aligned}
& n=\frac{1657}{1+1657(0.05)^{2}} \\
& =322.2168206 \\
& n=322 \text { (Nearest whole number). }
\end{aligned}
$$

Thus, the sample size for the study is 322 .

Thus, the sample size for the study is 322 .

Sample Technique

We used a systematic sampling technique to select the units of observation until the 322 given above was exhausted. The design was used because it produces the desired spread across the population of interest.

\section{Instrument AND Methods of DATA COLLECTION}

Three hundred twenty-two(322) copies of the questionnaire were distributed, while 321 were completed and returned. Thus showing a response rate of 99.7 percent. The data was Analyzed using inferential statistics. All tests were conducted at a 0.05 level of significance. This being the probability level at which we were ready to risk type I error. $\chi$

\begin{tabular}{|c|c|c|c|c|c|c|c|}
\hline \multirow[t]{2}{*}{$\mathrm{S} / \mathrm{N}$} & \multirow[t]{2}{*}{ Items of the Questionnaire } & \multicolumn{5}{|c|}{ Alternative Responses } & \multirow[t]{2}{*}{ Total } \\
\hline & & SA & A & $\mathrm{D}$ & SD & UND & \\
\hline \multirow[t]{2}{*}{1} & The activities of the godfathers are condoned by the party & 151 & 132 & 16 & 12 & 10 & 321 \\
\hline & $\begin{array}{l}\text { leadership because they are the main source of funding in the } \\
\text { party. }\end{array}$ & $(47.0)$ & $(41.1)$ & $(5.0)$ & $(3.7)$ & $(3.1)$ & (100) \\
\hline \multirow[t]{2}{*}{2} & That PDP is one of the most disorganized parties today in & 169 & 120 & 14 & 10 & 8 & 321 \\
\hline & $\begin{array}{l}\text { Nigeria is as a result of the manipulations of the godfathers in } \\
\text { the party. }\end{array}$ & $(52.6)$ & $(37.4)$ & $(4.4)$ & $(3.1)$ & $(2.5)$ & (100) \\
\hline 3 & $\begin{array}{l}\text { Godfathers are political entrepreneurs and their motive is } \\
\text { purely for profit consideration and not the welfare of the } \\
\text { people. }\end{array}$ & $\begin{array}{r}147 \\
(45.8)\end{array}$ & $\begin{array}{l}145 \\
(45.2)\end{array}$ & $\begin{array}{r}17 \\
(5.3)\end{array}$ & $\begin{array}{c}8 \\
(2.5)\end{array}$ & $\begin{array}{c}4 \\
(1.2)\end{array}$ & $\begin{array}{l}321 \\
(100)\end{array}$ \\
\hline 4 & $\begin{array}{l}\text { Imposition of candidates or name substitution by the } \\
\text { godfather triggers off party members defection or } \\
\text { carpet-crossing. }\end{array}$ & $\begin{array}{r}150 \\
(46.7)\end{array}$ & $\begin{array}{r}128 \\
(39.9)\end{array}$ & $\begin{array}{r}20 \\
(6.2)\end{array}$ & $\begin{array}{r}13 \\
(4.0)\end{array}$ & $\begin{array}{r}10 \\
(3.1)\end{array}$ & $\begin{array}{l}321 \\
(100)\end{array}$ \\
\hline \multirow[t]{3}{*}{5} & $\begin{array}{l}\text { In an attempt to satisfy godfathers by the godson, the } \\
\text { interest of the larger number is savagely undermined. }\end{array}$ & $\begin{array}{r}120 \\
(27.4)\end{array}$ & $\begin{array}{l}171 \\
(53.3)\end{array}$ & $\begin{array}{r}10 \\
(3.1)\end{array}$ & $\begin{array}{c}4 \\
(1.2)\end{array}$ & $\begin{array}{r}16 \\
(5.0)\end{array}$ & $\begin{array}{l}321 \\
(100)\end{array}$ \\
\hline & Total & 737 & 696 & 77 & 47 & 48 & 1605 \\
\hline & Percentage of Total & $(45.9)$ & $(43.4)$ & $(4.8)$ & $(2.9)$ & $(3.0)$ & $(100)$ \\
\hline
\end{tabular}

Data Analysis.

Table 1: The Effect of Godfathers on Internal Democracy

Source: field survey 2017

Note: Figures in parenthesis are percentages

$:(\mathrm{SA}=$ Strongly agree $; \mathrm{A}=$ Agree $; \mathrm{D}=$ Disagree $; \mathrm{SD}=$ Strongly disagree and UND $=$ Undecided $)$ 
From Table 1. it could be seen that on the average, 45.9 percent strongly agreed with all the statements of the item, 43.4 percent agreed but not strongly, 4.8 percent disagreed, 2.9percent strongly disagreed and 3.0 percent were indifferent. Thus indicating that on the whole, about 89.3 percent agreed with all the issues raised under the items.

The analysis presented in Table 4.2 indicates that 45

Table 2: Summary of Chi-square $\left(\chi^{2}\right)$ Test for Hypothesis

\begin{tabular}{|c|c|c|c|c|c|c|}
\hline \multirow{2}{*}{ Hypothese } & \multirow{2}{*}{$\begin{array}{l}\text { Sample } \\
\text { Size (n) }\end{array}$} & \multirow{2}{*}{$\begin{array}{c}\text { Degrees of } \\
\text { freedom }(\mathrm{df})\end{array}$} & \multicolumn{2}{|c|}{ Chi-Square $\left(\chi^{2}\right)$ values } & \multirow{2}{*}{$\begin{array}{l}\text { Significance } \\
\text { level }(\alpha)\end{array}$} & \multirow{2}{*}{$\begin{array}{l}\text { Decision } \\
\text { rule }\end{array}$} \\
\hline & & & $\chi_{\text {cal. }}^{2}$ & $\chi_{\text {crit. }}^{2}$ & & \\
\hline $\mathrm{I}$ & 322 & 16 & 89.267 & 26.296 & 0.05 & Rejected \\
\hline
\end{tabular}

Note: $\chi_{\text {cal }}^{2}$ means the calculated value of $\chi^{2}$ and $\chi_{\text {crit. }}^{2}$ means the critical value of $\chi^{2}$.

percent of the respondents on the average strongly agreed with all the statements of the items, 44.4 merely agreed, 6.6 percent disagreed, 2.6 percent strongly disagreed and an insignificant proportion of 1.6 percent were undecided thus showing that on the whole, about 89.4 percent agreed with all the issues raised under the items.

\section{DISCUSSION OF RESULTS}

The results indicates that the activities of the godfathers in a political party can significantly hinder the party from achieving and sustaining internal democracy. This result supports substantially the result of a study conducted by Obah-Akpowoghaha (2013) when he found in the first instance that 90 percent of the respondents interviewed in study agreed that the power of incumbency and godfathers greatly determine the emergence of party's candidates in any primary elections and that such negative influence undermines the credibility of elections and causes disaffection among party members whose voices are being suppressed. The implication of hijacking party primaries by moneybags/godfathers/party financiers is that the party is always in one form of crisis or the other always leading to endless court cases as it being presently witnessed in the PDP both at the State and national levels in Nigeria.

It is no longer a hidden fact that the politics of godfathers in Nigeria has become more visible and widespread like harmattan fire as events unfold itself. Elections of 1999, 2003, 2007, 2011,2014 and even 2017 in Nigeria has shown that godfathers has a firm grip on the country's democracy . Godfathers are political entrepreneurs who invest their resources to reap profits. It is indeed a dangerous trend because, with their presence, the issue of candidate imposition and substitution among political parties would never end with its grave consequences.

The study found that intra-party democracy is seriously being threatened by the activities of the godfathers and party financiers such activities are very glaring in the areas of candidates substitution after primary election to select party flag-bearers .Again is the decision on the composition of party leadership among other manipulations against the interest of the majority of party members.

\section{CONCLUSION}

The study concludes that Internal democracy is the foundation for real expansion of democracy in a developing society like Nigeria. It, therefore, calls for concern when members violate party constitution and display executive arrogance within the party, this act has not only torn many parties apart but also occasioned the decampment of many party stalwarts and crippled internal party democracy in Nigeria.

\section{RECOMMENDATIONS}

Based on the findings, the following recommendations were made:

- The influence of godfathers in party politics in Nigeria is on the rise. hence, necessary to adhere to party financial guidelines, re-defining of the legislative framework governing party registrations, functioning, and device measures to limit the role of godfathers and barons in party politics.

- There is also the need for reform of political financing, that is, the introduction of measures to strengthen parties to raise their own funds and also enhance their capacity to be more accountable and transparent in matters of party and campaign financing.

\section{REFERENCES}

[1] Akubo, A.A. \&Yakubu ,A.U. (2014).Political parties and democratic consolidation in Nigeria's Fourth Republic .Global Journal of Political Science and administration, 2, 79-89.

[2] Aniche, E.T. (2017). The 'David' and 'Goliath' and 2015 election outcomes in Nigeria: From the opposition to the ruling party. Insight on Africa: A Journal of Contemporary African Affairs, 10 (1): 1-16. DOI: 10.1177/095087817735385.

[3] Badejo, B.T., \& Obah-Akpowoghaha, N.G. (2015).The impact of cross-carpeting and multiplicity of political parties in the Nigerian democratic process. Journal of African Studies and Development, 7(8): 215-230.

[4] Bassey, N. \& Edet, E. (2008).Godfathers and good governance in Nigeria: An appraisal of Nigeria's Fourth Republic. Journal of Social Sciences and Policy, 2(4): 121-134.

[5] Bottomore, T. (1993).Elites and society. London: Routledge.

[6] Burnham, J. (1960).The managerial revolution. Bloomington: Indiana University Press.

[7] Chukwuemeka, E. (2012). Administration and politics in Nigeria past, present and issues. Lagos: Vinez Publishers.

[8] Chukwuemeka, E., Oji, R.O. \& Chukwurah, D.J. (2013). Give them their rights: A critical review of godfather and godson politics in Nigeria. Review of Public Administration and Management, 2(2): 129-140.

[9] CDD. (2017). One Election One Godfather: Elections and Godfathers in Anambra State. In Background Paper on the Anambra 18th November 2017 Governorship Election. Abuja: Centre for Democracy and Development (CDD).

[10] Dike, V. (2003). Nigeria and the politics of unreason: Assassinations, decampment, and moneybags. http://www.nigeriadeltacongress.com/articles/nigeriaandthepoliticsofu nre.ht Accessed on August 10, 2018

[11] Duverger, M. (1963).Political parties, their organisation, and activity in the modern state. New York: John Wiley \& Sons.

[12] Dye, T.R. (2000).Top-down policymaking. New York: Chatham House Publishers. 
[13] Egboh, E.A., \& Aniche, E.T. (2012). The state, political parties and crisis of internal democracy in Nigeria: A study of Peoples Democratic Party (PDP). Journal of Nigerian Government and Politics, 4(1):24-30.

[14] Giovanni, S. (1977).Parties and party system: A framework for analysis. Cambridge: Cambridge University Press.

[15] Gosnell, H.F. (1968). Machine politics: Chicago model. Chicago: University of Chicago Press.

[16] Ibeanu, O. (2008). State and economy in the Fourth Republic. In E. Amucheazi, and O. Ibeanu (Eds.)Between the theory and practice of democracy in Nigeria: An assessment of Obasanjo's first term in office by academic practitioners. London: Adonis and Abbey.

[17] Ikejiani-Clark, M. (2008).Party structures, funding, and discipline. In E. Amucheazi and O. Ibeanu (Eds.) Between the theory and practice of democracy in Nigeria: An assessment of Obasanjo's first term in office by academics and practitioners. London: Adonis and Abbey.

[18] Kura, S.B. (2011). Political parties and democracy in Nigeria: Candidates selection and party financing in the People's Democratic Party. Journal of Sustainable Development in Africa, 13: 268-298.

[19] Kura, S.B. (2014). 'Clientele' democracy: Political party funding and candidate selection in Nigeria. African Journal of Political Science and International Relations, 8(5): 124-127.

[20] Mbah, P. (2011) Party Defection and Democratic Consolidation in Nigeria, 1999-2009. Afro Asian Journal of Social Sciences, 2(2.3):1-21.

[21] Mersel, Y. (2006). The dissolution of political parties: The problem of Internal democracy. Oxford journals.org/content,4(1):84.

[22] Michels, R. (1915). Political parties: A sociological study of the oligarchical tendencies of modern democracy. New York: The Free Press.

[23] Mills, C.W. (2000). The power elite. Oxford: Oxford University Press.

[24] Ngige, N.C. (2008). Federalism and management of the internal security of the state. In E. Amucheazi \& O. Ibeanu (Eds.), Between the theory and practice of democracy in Nigeria: an assessment of Obasanjo's first term in office by academics and practitioners. London: Adonis and Abbey.

[25] Nnoli, O. (1986).Introduction to Politics. Ibadan: Longman.

[26] Nwagu, E.J. (2016). Political party financing and consolidation of democracy in Nigeria 1999-2015.International Journal of Political Science (IJPS), 2(4): 74-85.

[27] Nwede, O.N., Ibeogu, A.S. \& Nwankwo, O.U. (2014). Political Godfathers and governance in a developing democracy: Insight from Nigeria. Academic Journal of Interdisciplinary Studies, 3(4):137-143.

[28] Nworgu, B.G. (2006). Educational research: Basic issues and methodology.Nsukka: University Trust Publishers.

[29] Obah-Akpowoghaha, N.G. (2013). Party politics and the challenges of democratic consolidation in Nigeria.Research on Humanities and Social Sciences, 3(16):71-82.

[30] Odibachi, S. (2010,Nov.,10).Transforming phase of democracy.11 years after, National Daily Newspaper, retrieved from http://nationaldailyngr.com/index.php/article on20/04/2018.

[31] Ofuebe, C. and Anierobi, K. (2005). Political transitions in emergent democracies: A comparative analysis of electoral processes in Nigeria and Ghana (1999-2004). University of Nigeria Journal of Political Economy, 1(1): 139-151.

[32] Ogbeide, F.O.(2012). Leadership and political parties' crisis in Nigeria's Fourth Republic parties: A study of PDP and ACN. Asia-Pacific Journal of Social Sciences, 4(1): 1-20.

[33] Ojukwu, C. \& Olaifa, T. (2011). Challenges of internal democracy in Nigeria's political parties: The bane of intra-party conflicts in the Peoples Democratic Party of Nigeria. Global Journal of Human Social Science, 11(3):1-11.

[34] Okoli, A.C., \& Ali, H.A. (2014).Dialectics of intra-party opposition in Nigeria's Fourth Republic: Insights from the ruling People's Democratic Party (PDP). European Scientific Journal, 10(7): 249-259.

[35] Okonkwo, C.N. \& Unaji, F.N. (2016).Intra-party conflict and prospects of democratic consolidation in Nigeria.IOSR Journal of Humanities and Social Science (IOSR-JHSS), 21(5):91-98.

[36] Okoye, M. (1982).Party politics and election: Historical and functional analysis. Lagos: Malthus Press Publisher.

[37] Olaniyi, J.O. (2001). Foundation of public policy analysis. Ibadan: Sunad Publishers.

[38] Olorungbemi, S.T. (2014). Party conflicts and democratic consolidation in Nigeria, 1999-2007.International Journal of Humanities and Social Science, 4(11), 248-269.

[39] Omeje, K. (2010,Nov.11). Internal party democracy and the comeback of Atiku Abubakar ..Daily Independent Retrieved from http://www.independent.ngonline.com/dailyindependent/article 02/02/2018

[40] Orji, R.O., Eme, O.I. \& Nwoba, H.A. (2014). Political party funding in Nigeria: A case study of the People's Democratic Party (PDP). Arabian Journal of Business and Management Review, 2(11): 1-18.

[41] Osumah O. \& Ikelegbe A. (2009).The People's Democratic Party and governance in Nigeria, 1999-2007.Journal of Social Science, 19(3) :185-199.

[42] Pareto, V. (1935).The mind and society.San Diego: Harcourt, Brace\& Co.

[43] Pareto, V. (1991).The rise and fall of elites. New Jersey: Transaction Publishers.

[44] Putnam, R.D. (1976).The comparative study of political elites. New Jersey: Prentice Hall.

[45] Scarrow, S. (2004).Political parties and democracy in a theoretical and practical perspective: Implementing intra-party democracy. Washington, D.C.: NDI.

[46] Teorell, J. (1999). A deliberative defense of intra-party democracy, party politics. Fitzroy Dearborn Publishers.

[47] Varma, S.P. (1975).Modern political theory. New Delhi: Vikas Publishing House PVT. 